RESIDENT

\& FELLOW

SECTION

Section Editor

Mitchell S.V. Elkind,

MD, MS

Address correspondence and reprint requests to Dr. Ping Hong Lai, Faculty of National Yang-Ming University School of Medicine, Department of Radiology, Veterans General Hospital-Kaohsiung, 386 Ta-Chung First Rd., Kaohsiung, 813, Taiwan, ROC phlai@isca.vghks.gov.tw

\title{
Teaching NeuroImages: \\ Vanishing calvarium in Gorham disease
}

Figure $1 \quad$ Brain neuroimaging
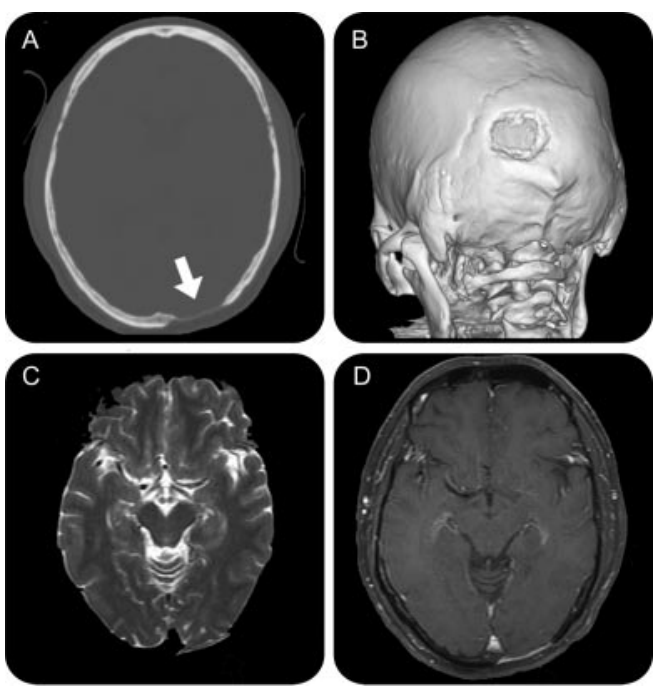

Head CT demonstrates focal calvarial thinning without new bone formation (A, B). The lesion has hyperintensity on T2-weighted imaging (C), enhances after gadolinium administration, and lacks a corresponding soft tissue mass (D).

A 46-year-old man had tenderness at the left occiput, without neurologic symptoms, for 5 years. Head CT and MRI (figure 1) disclosed focal calvarial thinning without a soft tissue mass, and normal brain parenchyma. A PET scan did not suggest malignancy. Histologic examination demonstrated dilated vascular channels and abundant fibrous tissue without osteoclasts or malignant cells (figure 2).

\section{Figure 2 Pathologic images}

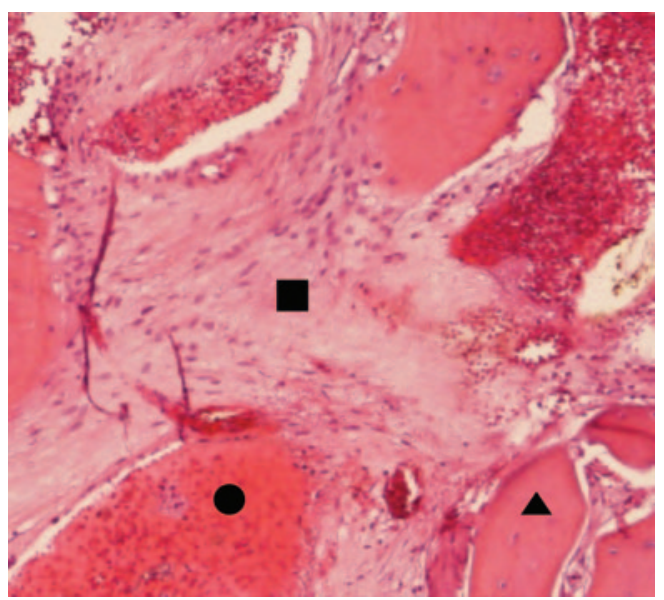

On histologic examination, abundant fibrous tissue $(\square)$ and dilated vascular channels $(\bullet)$ with hemorrhage have replaced most of the normal bone trabeculae ( $\mathbf{\Delta})$.

Gorham disease is characterized by proliferation of the vasculature of the bone in the early stage, followed by gradual osteolysis and fibrous replacement. ${ }^{1,2}$ MRI may help determine the stage of the disease. ${ }^{2}$ In our case, the lack of prominent vessels may indicate a later stage of disease.

\section{REFERENCES}

1. Lo CP, Chen CY, Chin SC, Juan CJ, Hsueh CJ, Chen A. Disappearing calvarium in Gorham disease: MR imaging characteristics with pathologic correlation. Am J Neuroradiol 2004;25:415-418.

2. Kai B, Ryan A, Munk PL, Dunlop P. Gorham disease of bone: three cases and review of radiological features. Clin Radiol 2006;61:1058-1064.

From the Departments of Radiology (C.L.C., S.C.L., P.H.L.), Neurosurgery (S.S.H.), and Pathology (H.H.T.), Kaohsiung Veterans General Hospital, Kaohsiung; and School of Medicine (P.H.L.), National Yang-Ming University, Taipei, Taiwan.

Study funding: Supported by the National Science Council (NSC-97-2314-B-075B-010-MY3) and the Veterans General Hospital-Kaohsiung (VGHKS99-66).

Disclosure: The authors report no disclosures. 


\title{
Neurology
}

\author{
Teaching NeuroImages: Vanishing calvarium in Gorham disease \\ C.-L. Chiang, S.-S. Hsu, S.-C. Li, et al. \\ Neurology 2010;75; 65 \\ DOI 10.1212/WNL.0b013e3181f736b5
}

This information is current as of October 11, 2010

Updated Information \&
Services

References

Subspecialty Collections

Permissions \& Licensing

Reprints including high resolution figures, can be found at: http://n.neurology.org/content/75/15/e65.full

This article cites 2 articles, 0 of which you can access for free at: http://n.neurology.org/content/75/15/e65.full\#ref-list-1

This article, along with others on similar topics, appears in the following collection(s):

All Headache

http://n.neurology.org/cgi/collection/all_headache

CT

http://n.neurology.org/cgi/collection/ct

MRI

http://n.neurology.org/cgi/collection/mri

Information about reproducing this article in parts (figures,tables) or in its entirety can be found online at:

http://www.neurology.org/about/about_the_journal\#permissions

Information about ordering reprints can be found online:

http://n.neurology.org/subscribers/advertise

Neurology ${ }^{\circledR}$ is the official journal of the American Academy of Neurology. Published continuously since 1951, it is now a weekly with 48 issues per year. Copyright Copyright (? 2010 by AAN Enterprises, Inc.. All rights reserved. Print ISSN: 0028-3878. Online ISSN: 1526-632X.

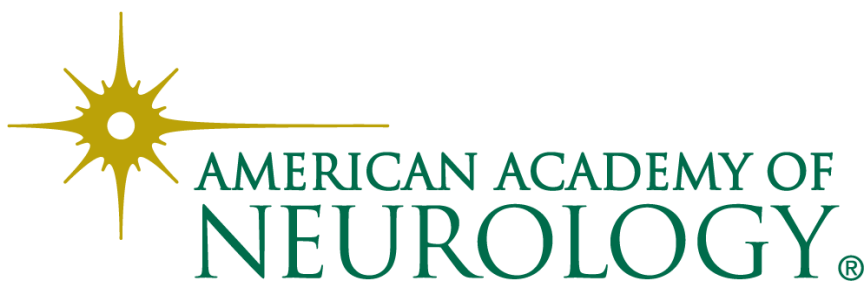

